\title{
217 無線センサネットワーク＼cjkstart現状と課題*
}

クロスボー株式会社 中村千代賢

Keywords: Sensor, Network, ZigBee, SP100, Wireless, Adhoc, Multihop, Ubiquitous

\section{1. 精}

近年 ZigBee など各種の無線センサネットワークが 提唱されているが、アドホック・マルチホップで安定 動作するシステムはまだ少ない。クロスボーMOTE は早期より製品化されたそのようなシステムで、長期 稼動した実績を通じセンサネット実用上の条件が検証 されている。MOTE を主とした技術の紹介と共にセ ンサネット全般の応用展開に必要な要素と条件を考察 する。

\section{2. 無線センサネットワークプラットフォーム}

センサネットワークの基本となる構成要素はセンサ を搭載したセンサノードである。センサノード上で はセンサデータのセンシングや他のセンサノードと 自律的にネットワークを構筑しセンサデータを送信 する処理を行うためのソフトウエアが実行される。

実際にセンサネットワークを構築・利用する際に はこのセンサノードに加えて、センサネットワーク で集められたセンサデータを処理するゲートウェイ PCのソフトウエア、さらにはそのデータをユーザ が見やすくする、或いけセンサデータの值に応じて 別の機器を制御したりする、クライアントPCのソ フトウエア・システムも必要となる。

またセンサネットワークは各種の用途があるため、 それぞれの目的に応じてセンサをつけかえられるよ うな柔軟性のあるハードウェアや、それらセンサの ドライバ、ネットワークプロトコルスタックを開発 できるようなセンサノード上のソフトウエアプラッ トフォームとその開発環境も必要となる。

ここではそれらをまとめてセンサネットワークプ ラットフォームと乎ぶ。センサネットワークに使わ れるセンサノードは小型・電池駆動であることが求 められるため、センサネットワークプラットフォー ム全体で省資源・省電力へのさまざまな対策が行わ れる。
確立されたセンサネットワークプラットフォーム の存在により、多くの開発者がセンサノードハード ウエア、センサノード上のアプリケーション・ネッ トワークプロトコルスタックなよ゙のソフトウエア、 センサデータを処理するシステムを開発することが でき、それらがさらにプラットフォーム自身の機能 を高めていくことになる。このことがセンサネット ワークそのものの進歩にも貢献する。

\section{MOTE}

MOTEはセンサネットワークプラットフォームの 一例である。MOTEが広く利用されているのは、早 い時期に製品化されたことに加えてオープンソース で開発された TinyOS をそのソフトウエアプラット フォームとしており、センサネットワークそのもの の研究開発にも数多く採用されたためである。セン サネットワークの実利用が進むにつれ MOTE も研 究開発用途か-ら実利用へと利用形態が広がり 2005 年末には Crossbow社よりメッシュネットワークレ イヤ、サーバレイヤ、およびクライアントアプリが 統合されたソフトウェアスイートMoteWorks が発表 された。これは大規模・実利用ベースのセンサネッ トワークを想定したものであり、特定用途の低コス ト・カスタムセンサノード開発までも可能としてい る。

\section{4. ハードウェア}

一般的にセンサノードは無線通信機能とセンシン グ機能、そして無線通信チップやセンサを制御する ためのマイクロコントローラ、電源を搭載している。 センサネットワークのハードウェアに求められてい ることは、まず低消費電力である。これ電源イン フラのない場所で利用するために電池駆動を前提と し、かつ電池交換作業を極力なくしたいことから当 然のことである。さらに設置場所を選ばないよう小 
型であることも重要である。また大規模なセンサネ ットワークでは多数のセンサノードを使うことにな るためコストも極力低いことが求められる。

これに加えて現在のようにセンサネットワークの マスマーケットが明確になっていない状況では多様 なアプリケーションに使えるような配慮も求められ る。具体的にはさまざまなアプリケーションを動か すことが出来るような汎用のマイクロコントローラ を搭載し、目的に応じたセンサを簡単に取り付けら れるようなインタフェースを備えていることが望ま いい。

現在の MOTE ではマイクロコントローラに Atmel 社の ATmega128L を使い、無線通信方式は Chipcon 社の CC2420を使用した IEEE８02.15.4 となってい る。シリーズの大きな特徴はマイクロコントローラ 十無線通信チップ部とセンサボード部とが別になつ ていることである。先に述べたようにこの特徴によ り目的に応じたセンサを簡単に取り付けることがで きる。マイクロコントローラとして使われている ATmega128L はRISCアーキテクチャの 8bit マイクロ コントローラである。プログラム格納用 $128 \mathrm{~K}$ バイ トのフラッシュメモリや、動作用 SRAM を内蔵し、 10bitの $\mathrm{AD}$ コンバータによるアナログ入力、デジタ ル入力、I2C、SPI、UART といった沉用的なインタ フェースも備えている。これら内蔵機能によりセン サノードの小型化を実現しながらも多様なインタフ エースを持つセンサからの情報を処理できるように なっている。後述する TinyOSではマイクロコント ローラが極力低消費電力状態になるように配慮され ており、この仕組みとあわせてセンサノードの低消 費電力化を実現している。ノードにはマイクロコン トローラ内蔵のものとは別にデータ格納用に外部フ ラッシュメモリが搭載されている。データ通信速度 の制限などからセンサデータを即時にネットワーク へ送信できない場合など、このフラッシュメモリに データを溜めておくことが可能である。

無線通信ついては諸外国では ISMバンドと称す る周波数帯が割り当てられているが日本ではその制 度がないため初期には $315 \mathrm{MHz}$ の微弱電波が使用さ れ通信距離上の制約があった。現在は無線チップ CC2420を使った MOTE(MICAz) が登場したため無 線通信の信頼性は劇的に向上し、日本国内で電波法 の技術適合をうけた機種もある。MICAzに搭載さ れているCC2420は IEEE802.15.4に準拠した無線通 信チップであるため物理層は IEEE802.15.4に従い周 波数帯は2.4GHz帯、O-QPSK・DSSS 方式で通信速
度は250Kbpsである。MAC層に関しては一部ソフ トウエア実装に依存するため IEEE802.15.4をフルサ ポートするかどうか性用者に任されている。

MICAzに搭載されるセンサネットワークプロトコ ルスタックであるXMesh は現バージョンでは IEEE802.15.4MAC 層のフルサポートはしていない。 また CC2420 の消費電流は受信時約 20mA、送信時 は約 18mA である。IEEE802.15.4は ZigBeeに採用さ れていることからも最近注目を集めている無線通信 規格である。厳密には ZigBee は IEEE802.15.4が規定 する物理層・MAC 層を含めて、これよりも上位層、 つまりネットワーク層・アプリケーション層といっ た階層までを含んだ規格であり IEEE802.15.4そのも のを指寸ものではない。MICAzでは上位層には後 で述べるXMeshを採用しているのでそのままでは ZigBee 対応機器と通信することはできない。ただし 物理層が同じIEEE802.15.4であるため ZigBee プロト コルスタックを採用して ZigBee機器と通信させる ことは可能であるため Crossbow は XMesh の将来の バージョンでZigBee機器との通信をサポート予定 であるとしている。

センサに関しては、AtMega128L分数々の GPIO と

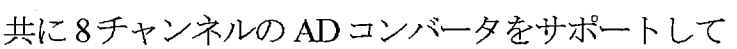
いるため数々のセンサを搭載できるが、運用検証に 使用できるセンサ搭載済基板および高精度 $\mathrm{I} / \mathrm{O}$ 基板 が Crossbow より供給されている。

\section{5. ソフトウェア}

MOTE で使われるソフトウエアプラットフォーム は TinyOS という無線センサネットワーク用にデザ インされた OSである。オープンソースプロジェク 卜として開発され、多くの開発者によって機能の追 加や改良が行われている。情報交換・サポート用の メーリングリストや、今後の機能拡張について議論 するワーキンググループもある。

TinyOS はセンサネットワークプラットフォーム 全体で求められている省資源・省電力を満たすよう デザインされている。非常に軽量であり最近の一般 的な OS とは異なり、プリエンプティブなマルチタ スクやメモリ保護機能といったサービスは提供しな いため OS というよりハードウェア制御やネットワ ークプロトコルスタックなどのソフトウエアライブ ラリから構成されるアプリケーションフレームワー クという方が正確之言える。TinyOS は軽量である 一方で一般的な OS と同様にハードウェアからアプ 
リケーションまで階層化されたモジュール構造をし ており、開発者はハードウエアなど下位層の詳細を 意識せずにアプリケーションを開発することができ る。このように豊富なソフトウエアライブラリとモ ジュール構成、無䭾な処理を極力行わないように配 慮されたアプリケーションフレームワークにより、 限られた資源下で高いパフォーマンスを実現するこ ととソフトウエアの開発効率を上げることとのバラ ンスをうまくとっているといえよう。

TinyOS の根幹は nesC という、C言語を拡張した TinyOS 用のプログラミング言語である。nesCには TinyOS でのプログラミングをサポートするために いくつかのC言語拡張が含まれている。主な拡張 部分は、コンポーネントプログラミングに関するも の(ワイアリング)とタスク処理に関するものの $2 つ$ に集約される。JavaやC+rんいったオブジェクト指 向言語がクラス(class)を基本単位としてプログラム を組み上げていくように、nesCではコンポーネン ト(component)を組み上げてプログラムを作る。また クラスがメソッドや継承によって相互に結び付けら れるように、コンポーネントはインタフェース (interface)に含まれるコマンド(command)やイベント (event)によって相互に結び付けられる。コマンドは クラスのメソッドとほぼ同じものと考え、コンポー ネントのある機能を表すものである。コンポーネン 卜を利用する(use)側は nesC の拡張構文の一つであ る call文を使ってコンポーネントのコマンドを呼び 出す。したがってコマンドの実装はそのコマンドを 含むインタフェースを提供する(provide)側が行う。 コマンドの呼び出しはクラスのメソッド呼び出しと 同じことである。

イベントはコンポーネント内で起こる事象を表す ものである。イベントはコマンドとは逆にインタフ ェースの提供側ではなく、利用側が実装する。これ はインタフェースの提供側がイベントの発生を signal文によって通知し、それによって利用側が実 装したイベント処理が呼び出されるためである。ク ラスと対比させるならば、イベントとはクラスの仮 想関数であり派生クラス、つまり利用側がこれをオ ーバライドすることと考えれば理解しやすい。

\section{6. 実稼動について}

センサネットの実稼動上、最も重要視される 電池 寿命、センサデータの精度、通信の信頼性、の3つ の要素で考える。
電池寿命の延長は間久動作をさせ、所謂スリープ 時間を多くとることにより寒現する。センサネット メーカーの多くは電池の容量加理論值を算出して カタログに電池寿命を記載する傾向が見受けられる が、実のところノード動作通りの閒久電流データは 電池メーカーには無いため、実際に長時間運用し検 証しないとかなり菊龉が出る。また、実運用の問題 のひとつとして電池そのもののばらつきが大きい事 が挙代られる。具体的には、新品の電池の約 $10 \%$ は 想定容量より明確に低寿命であるのが一般的だが、 電池メーカーは容量の保証はしないという実態があ る。

センサデータの精度は、センサ素子の誤差に依存 するだけでなく、ノード上の実装場所や筐体の気密 性にも関係がある。後者は設計時に織り込めばよい が前者はドリフトなどを考えると間欠動作下でのセ ンサ出力の再現性が問われ、これもセンサの仕様と しては一般的ではないため個別の検証が必要となる。 更に、計測したい現象が振動など高速サンプリング を必要とする場合は間欠動作ができないばかりかデ 一タ即ちパケット数も多大となり電力消費に影響を 与光る。

通信の信頼性に関しては、無線 LAN等のチャン ネルを避けた周波数を選定した場合においてもシミ ユレーションで網羅しきれない現実的動乱要因を考 慮する必要がある。例えば複数の人間の位置、夜間 工事、ドアの開開、電子機器の妨害などが複合的に 干渉しあうためマルチホップの伝播経路の変化は通 常考えるより激しい。この点、ZigBee が提唱するよ うに末端ノード(RFD)によるデータ中継が不可能で あると経路の選択範囲が少なく通信経路の冗長性が 失われる。一方、Xmeshが提唱する末端ノードも中 継が可能な方式であると経路選択に有利と言える。 いずれのシステムの場合もセンサノードからのトラ ヒックがゲートウェイに集中することは同様で、 ード数とサンプリング間隔は相互に依存する。

アドレス割当やセキュリティなどは近日中のバー ジョンアップで解決されるが、上記の 3 要素は恒久 的に実使用上で常に考慮されるべき条件として残る。 どのレベルの運用が現行センサネットとして可能で あるかといらユーザー知識が、過去 10 年のインタ 一ネットの普及がそうであった如く、段階的に浸透 することによってより現実的なアプリケーションが 見出されると期待できる。 


\section{References :}

http:/www.tinyos.net/tinyos-1.x/doc/tutorial/

http://www.sourceforgenet/projects/tinyos/

http://www.xbow.jp/zigbee-smartdusthtml

http://webs.cs.berkeley.edu/retreat-1-04/slides/buonadoma-

NEST_01_04.pdf

本資料で言及される商標は、商標所有者の財産です。 